\title{
Assessment of Turkey-Nigeria Trade Relations from 2000 - 2018
}

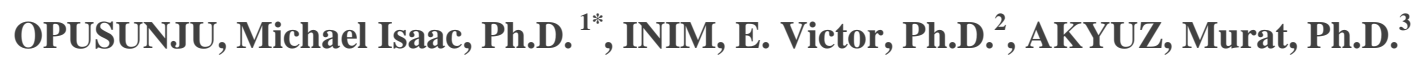 \\ ${ }^{l}$ Department of Business Administration Nasarawa State University, Keffi, Nigeria \\ ${ }^{2}$ Department of Accounting Nile University of Nigeria, Abuja, Nigeria \\ ${ }^{3}$ Department of Business Administration Nile University of Nigeria, Abuja, Nigeria
}

*Corresponding Author: OPUSUNJU, Michael Isaac, Ph.D., Department of Business Administration Nasarawa State University, Keffi, Nigeria.

\begin{abstract}
The study assess Nigeria - Turkey trade relations from 2000-2018. The study adopted ex-post facto research design. Data on import from Turkey to Nigeria and export from Nigeria to Turkey were documented on the website of National Bureau of statistics from 2000 to 2018. The study used T-test to analysed the data and the findings showed that Nigerian government benefited more from trade relations with Turkey while Turkish government benefited less from trade relations with Nigeria. The study recommended that Nigerian Government should increase the volume of export of goods to Turkey. They should continue to focus on export of agricultural output to Turkey since Nigerian government benefited more Also, Turkish Government should re-strategies on how to gain more from engaging in import trade with Nigerian government. They should use the advantage that their currency is more appreciated than Nigerian currency to gain from trade relations with Nigeria.
\end{abstract}

Keywords: Trade Relations, Export and Import

\section{INTRODUCTION}

Nigeria engagement with Turkey in trade transaction is beneficial to both countries since Nigeria export goods to Turkey and Turkey import goods to Nigeria. The trade relations between Turkey and Nigeria allow inflow of goods to both countries and these counties benefited from what they cannot produce satisfactorily using available resources at their disposal. The idea of Adam Smith is that counties like Nigeria and Turkey can engaged in trade relations when both countries can produce goods at lower price and good at higher price using high labour and capital as well as low labour and low capital. The essence of Turkish trade relations is that Nigeria can buy from Turkey on those goods they have deficiencies in producing them at low labour and low capital while Turkey also buy from Nigeria with those goods that they have deficiencies in producing them with low capital and low labour cost. Also, trade relations is to bring specialization on those goods a country is enable to efficiently and effectively produced with low capital and low labour. Nigeria and Turkey can benefit from both countries deficiencies and try to specialize on the one that they cannot produce effectively and efficiently.

In the last one and half decade of trade relations between Nigeria and Turkey, the major problem of this study is that it is not clear whether Government of Nigeria benefited more from trade relations with Turkey or whether Turkey government benefited more from trade relations with Nigeria. From the research carried out by the researchers in this field. None of the studied research by the researchers assess the trade relations between Nigeria and Turkey for the period of 19 years from 2000-2018.

The objective of this study is to assess Nigeria - Turkey trade relations from 2000-2018, a 19 years period. The specific objectives of this study is to examine whether Nigeria benefited more from engaging in trade relations with Turkey and also to evaluate whether Turkey benefited more from engaging in trade relations with Nigeria.

The scope of this study is Nigeria - Turkey trade relations for the period of 19 years from 2000-2018. The period is chosen because it involved a democratic era when Nigeria open borders to allow inflow of goods from Turkey to Nigeria and also from Nigeria to Turkey.

The hypotheses are stated below as: 
$\mathrm{H}_{01}$ : Nigeria does not benefited more from engaging in trade relations with Turkey for the past 19 years

$\mathrm{H}_{02}$ : $\quad$ Turkey does not benefited more from engaging in trade relations with Nigeria for the past 19 years

\section{Turkey Nigeria Trade Relations}

The Turkey-Nigeria trade relations started in Nigeria in 1960 and after Nigeria gained independent, the government of Turkey opened an Embassy in Lagos in 1962 (Republic of Turkey's Ministry of Foreign Affairs, 2017). As the capital of Nigeria change to Abuja in 1991, the Turkey government shipped their embassy to Abuja in 2001 for more economic activities. Also, Nigerian government built their embassy in Ankara which is the capital of Republic of Turkey. 1980's ending recorded commercial contracts activities (private business firms) in Turkey and Nigeria. Turkey-Nigeria relations are move by Turkish government towards globalization in 1989 (Turkish Press Review, 2005). The economic and business or commercial reason for Turkey and Nigeria trade relations is growing rapidly since independence in 1960 in Nigeria. The Turkey government import oil and gas from Nigeria which made Nigeria biggest in Sub-Sabaran African in 2014. Many Turkey companies such as construction, manufacturing, school, hospital and energy sectors are operating in Nigeria (MFA, 2017). Turkey and Nigeria signed a memorandum of understanding (MoU) on trade and economic partnership agreement (TheWill, 2016) and Turkey-Nigeria relations have also witnessed movement of people between both countries parallel with developments in trade, and there has been a consistent rise in arrivals of Nigerian nationals to Turkey since 2000.

\section{CONCEPTUal Model}

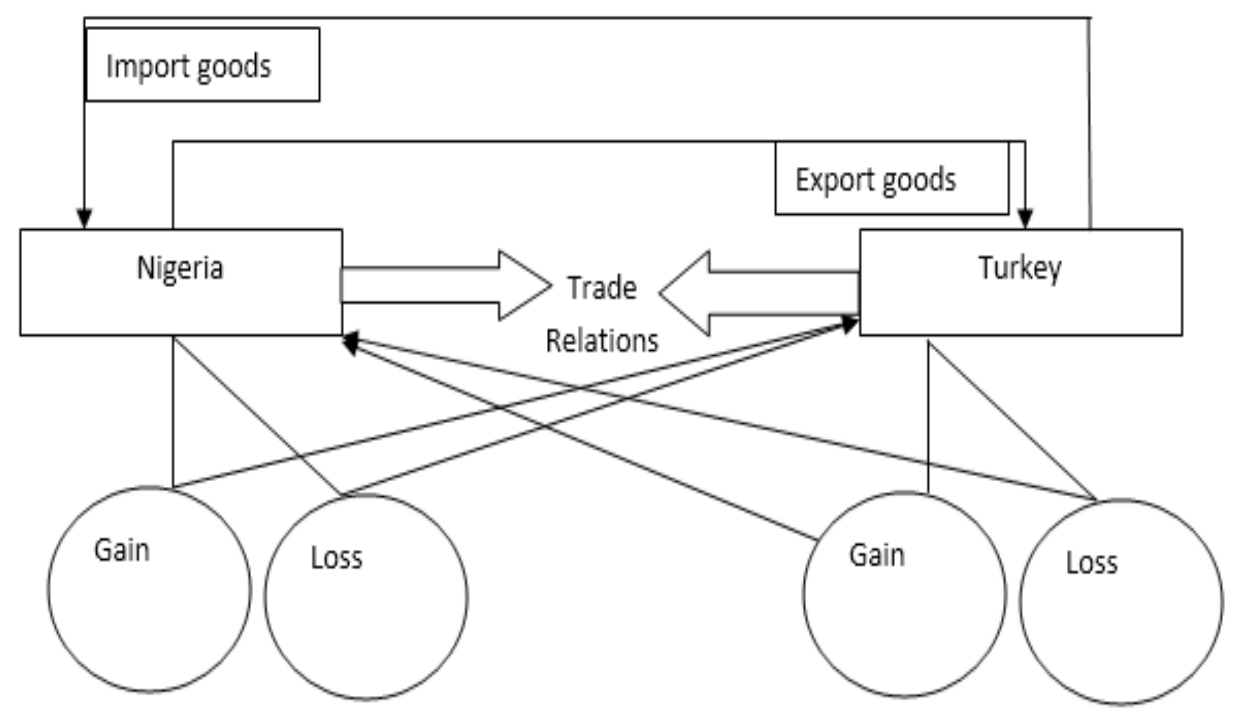

This model is conceptualized to explain trade relations between Nigeria and Turkey. The model believed two countries must engage in trade relations and these two countries must be able to export goods from the other country as well as importing goods from other country also. The two countries must have something unique that called for exchange. Price and volume of goods must be considered when engaging in trade relations with any given country of the world. The model believed that Nigeria must export goods to Turkey while Turkey must import goods to Nigeria in order for trade relations to exist. The model further believes that engaging in trade relations is either gain or loss. Any given countries that engaged in trade relations expect to gain from trade relations or loss from engaging in trade relations. The principles guiding international trade is that one country may gain from the other country or loss from the other country for trade relations to exist. Therefore, Nigeria may gain from engaging in trade relations or loss. Also, Turkey may gain or loss for engaging in trade relations with Nigeria.

\section{Methodology}

The study adopted ex-post facto research design. The reason is that data collected from National Bureau of statistics in Nigeria is a time series data. The reason for obtaining data from National 
Bureau of Statistics in Nigeria is that they are unique and reflect the trade relations of Turkey and Nigeria. However, data on import from Turkey to Nigeria and export from Nigeria to Turkey are documented on the website of National Bureau of statistics from 2000 to 2018. The study used T-test to analysed the data with the aid of e-view version 9.00 statistical package. The t-test is used because it indicate a significant different between export from Nigeria to Turkey and import from Turkey to Nigeria. The study also used chart and table. The reason for using chart is to indicate properly analysis on how import and export trade activities are carried out in the two counties engaging in trade relations.

\section{Data AnAlysis AND Discussion}

Export

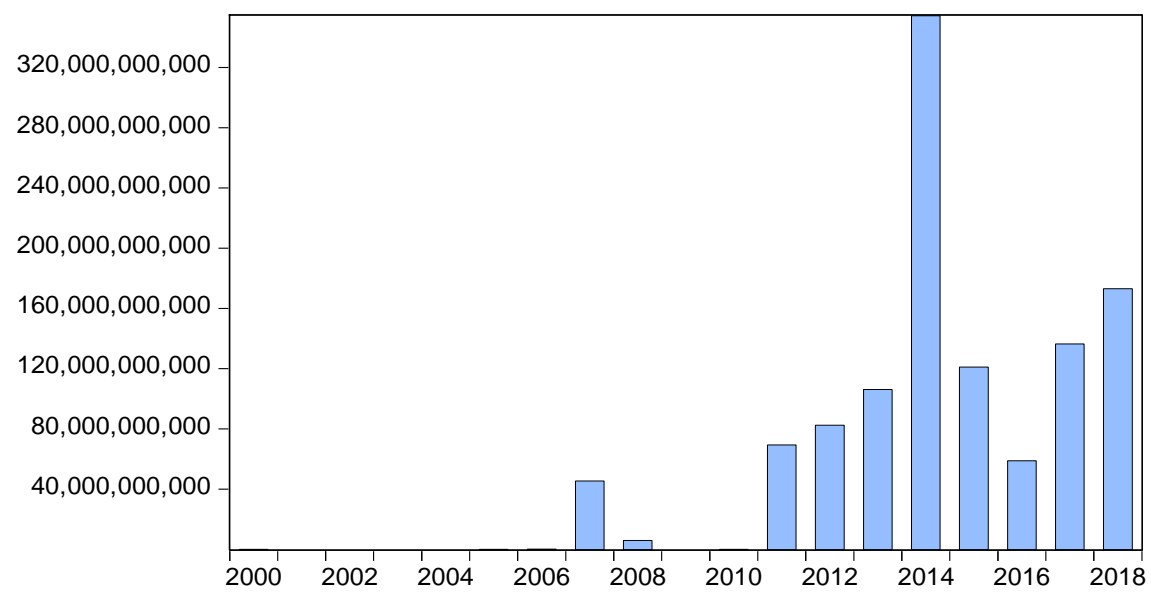

Fig1. Export of Goods from Nigeria to Turkey

From figure 1, Nigeria export goods from Turkey at a very low rate (N1068348) in 2000 but export trade in from Nigeria to Turkey stop in 2000. The 2001, 2002, 2003 and 2004 recorded that Nigerian Government did not engaged in export of goods from Nigeria to Turkey. For the past four years, that is 2001-2004, Nigerian government did not export any goods to Turkey. In 2005, Nigerian Government now started to engage in export of goods with a very lower rate of N8056396. Also, 2006 recorded very little difference in the amount of export of goods to Turkey (N206913162). However, it was in 2007 that there was a very little improvement in export of goods from Nigeria to Turkey with N45580415012 exports trading. Export trade from Nigeria to Turkey recorded a dropped in 2008 with N6081819162 but this dropped was not bad compared to the one in 2009 (N5437). In 2010, the export of goods from Nigeria to Turkey recorded a much dropped (N71447335) but with an improvement to the one in 2009 which implies that Nigerian Government had to re-strategies on what they export to Turkey in 2010 to recorded such improvement. In 2011, 2012 and 2013, it is noted that export of goods from Nigeria to Turkey started to increase at an increasing rate of N69337077985, N82496551208 and N106242467588.97 but this increased was highly increase in 2014 when Nigerian government recorded export trade of N354539171135.70. The increased in export of goods was not sustained in Nigeria because the year after 2014 which is 2015 recorded a dropped of export of goods from Nigeria to Turkey with N121155200123.30. Also, in 2016, export of goods from Nigeria to Turkey dropped with (59025986109.18) and the dropped in 2016 was much than 2015 which implies that 2016 recorded reduction in export of goods from Nigeria to Turkey.

Finally, in 2017, export of goods from Nigeria to Turkey started to increase with N136455067880.26. The reason may be that Nigeria started encouraging agricultural farming and the Nigerian government started to export some agricultural output to Turkey. Also, in 2018, export of goods increased and the increased was more than the one in 2017. The reason is that agricultural business in well structured in Nigeria to encourage export of such output.

From the figure, the import of goods from Turkey to Nigeria is recorded from 2000 to 2018, a 19 years period. Import of goods in 2000 was very little which was about N1952748831, but 2001, recorded a very little improvement in the importation of goods from Turkey to Nigeria at N2372074774. However, the difference is unique that encourages Turkey to engaged in trade with Nigeria. After, 2001, the 2002 also recorded an improvement of N3426363179, though the 
improvement is not much but it is a way of encouraging Turkish government to engaged in trade relations with Nigeria. Also, 2003, recorded decrease in import of goods from Turkey to Nigeria at N3162588305 but the Turkish government recorded increase (N5338911534) in the following year which is 2004 which was encouraging. However, there was no import of goods from Turkey to Nigeria in 2005. In 2006, government of Turkey import goods from their country to Nigeria that amounted to N9924497871 but this was a little improvement in import of goods to Nigeria. Also, 2007 recorded reduction in the increase/improvement in import of goods from Turkey to Nigeria with N11708355451. The difference was very significant and in 2008, import of goods from Turkey to Nigeria recorded an increase of but 2009 recorded increase N47951561996 of import of goods from Turkey to Nigeria. Also, the 2010 recorded decrease in import of goods from Turkey to Nigeria with N40505898785.

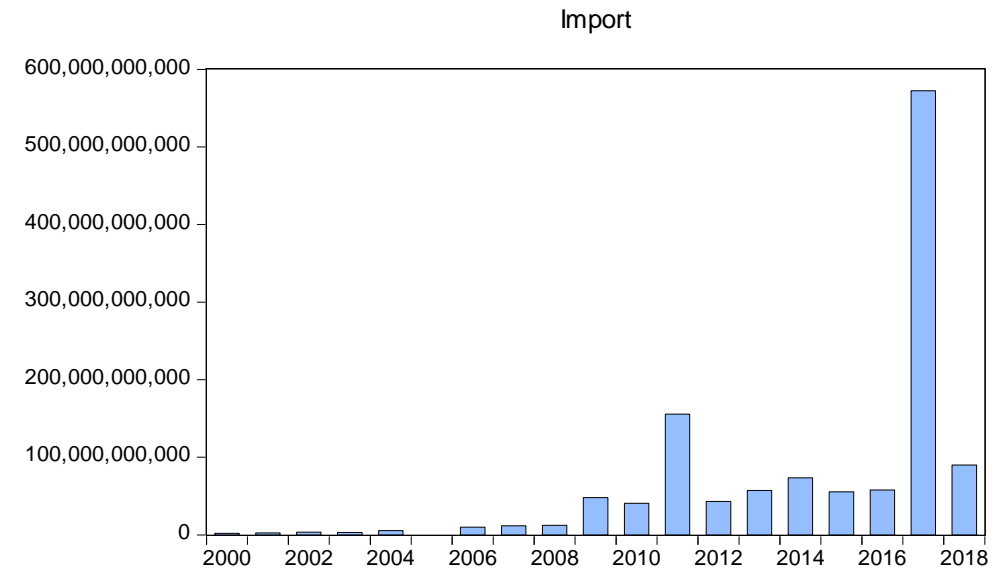

Fig2. Import of Goods from Turkey to Nigeria

Moreso, the import of goods from Turkey to Nigeria recorded an increase of 155501978358 in 2011. Also, there was an increase of import of goods from Turkey to Nigeria in 2012, 2013 and 2014. This increased was not sustained due to decreased in import of goods from Turkey to Nigeria in 2015 and 2016. In 2017, the import of goods was very high increase at N572358155848.94 but there was also reduction in import of goods from Turkey to Nigeria in 2018.

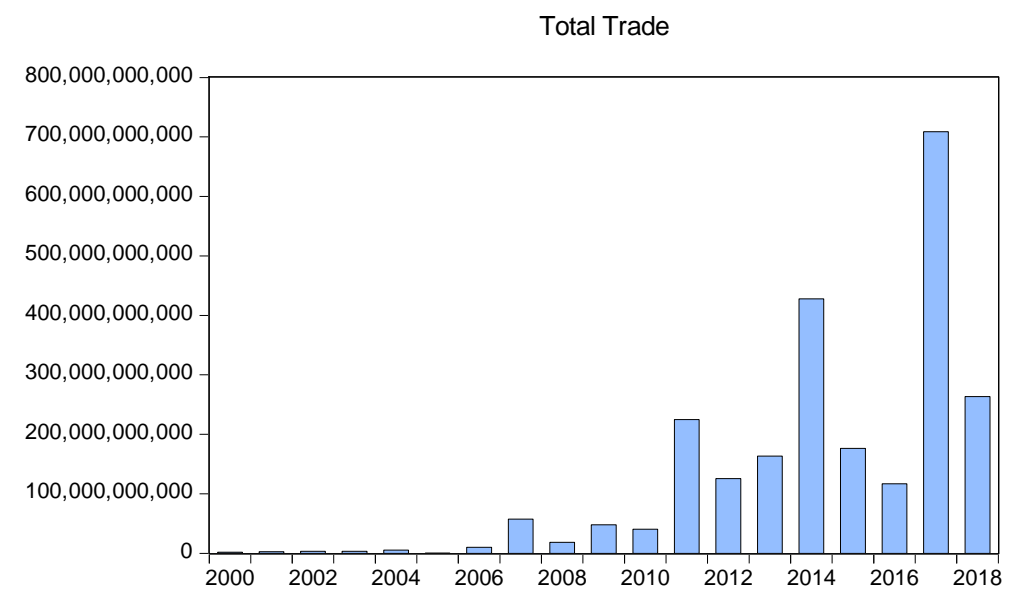

Fig3. Total Trade between Turkey and Nigeria from 2000 to 2018

Nigeria engagement of trade relations with Turkey bring the total volume of trade ( import plus export) of goods. The figure revealed that there was very little trade in 2000, 2001, 2002, 2003 but it was in 2004 that trade between the two countries started to improved but the improvement in the trade between Turkey and Nigeria did not last since in 2005, trade was very low which implies that it dropped. However, 2006 trade between the two countries recorded an increase at very small rate but in 2007, trade between the two countries started to increase but the increased in trade relations in 2007 was not last since the following year recorded decrease in trade relations, that is 2008 recorded decrease in trade relations between the two countries that involved in trade. 
Trade in 2009 was recorded an increase which was an improvement from the previous year but this increase did not sustain in 2010. The 2010 trade relations recorded decreased at very lower rate compared to 2009. There was very moderate increase in trade relations between Turkey and Nigeria in 2011 but this increase decreased in 2012 and 2013. The decrease of trade relations between Turkey and Nigeria recorded an improvement in 2013 compared to 2012. This implies that 2012 was lower than 2013 in their decrease compared to 2011. Trade relations between Nigeria and Turkey had a very high increased in 2014 but it also recorded decrease in 2015 and 2016. The decreased in 2016 was very poor compared to increase in trade in 2014. However, 2017 trade relations between Nigeria and Turkey recorded drastic increase but this drastic increased did not sustained due to decreased in trade between Nigeria and Turkey in 2018.

Table1. Trade balances between Turkey and Nigeria

\begin{tabular}{|c|c|c|c|c|c|c|}
\hline \multirow[t]{2}{*}{ Years } & \multirow[t]{2}{*}{$\operatorname{Export}(\mathbf{N})$} & \multirow[t]{2}{*}{ Import (N) } & \multicolumn{2}{|l|}{ Nigeria } & \multicolumn{2}{|l|}{ Turkey } \\
\hline & & & Gain & Loss & Gain & Loss \\
\hline 2000 & 1068348.00 & 1952748831.00 & & (1951680483) & 1951680483 & \\
\hline 2001 & & 2372074774.00 & & $(2372074774)$ & 2372074774 & \\
\hline 2002 & & 3426363179.00 & & (3426363179) & 3426363179 & \\
\hline 2003 & & 3162588305.00 & & (3162588305) & 3162588305 & \\
\hline 2004 & & 5338911534.00 & & (5338911534) & 5338911534 & \\
\hline 2005 & 8056396.00 & & 8056396 & & & $(8056396)$ \\
\hline 2006 & 206913162.00 & 9924497871.00 & & (9717584709) & 9717584709 & \\
\hline 2007 & 45580415012.00 & 11708355451.00 & 33872059561 & & & $(33872059561)$ \\
\hline 2008 & 6081819162.00 & 12231806128.00 & & (6149986966) & 6149986966 & \\
\hline 2009 & 5437.00 & 47951561996.00 & & $(47951556559)$ & 47951556559 & \\
\hline 2010 & 71447335.00 & 40505898785.00 & & $(40434451450)$ & 40434451450 & \\
\hline 2011 & 69337077985.00 & 155501978358.00 & & $(86164900373)$ & 86164900373 & \\
\hline 2012 & 82496551208.00 & 42983824565.00 & & $(34737273357)$ & 34737273357 & \\
\hline 2013 & 106242467588.97 & 57222185494.00 & 49020282094.97 & & & $(49020282094.97)$ \\
\hline 2014 & 354539171135.70 & 73330388234.00 & 281208782901.7 & & & $(281208782901.7)$ \\
\hline 2015 & 121155200123.30 & 55273094558.00 & 65882105565.3 & & & $(65882105565.3)$ \\
\hline 2016 & 59025986109.18 & 57898162349.49 & 1127823759.69 & & & $(1127823759.69)$ \\
\hline 2017 & 136455067880.26 & 572358155848.94 & & (435903087968.68) & 435903087968.68 & \\
\hline 2018 & 173173231494.28 & 90111594557.23 & & $(399184924354.66)$ & 399184924354.66 & \\
\hline
\end{tabular}

Source: National Bureau of Statistics and Author Computation, 2019

The above table showed the export of goods from Nigeria to Turkey, import of goods from Turkey to Nigeria, total trade gain by countries engaging in export and import in Nigeria and Turkey. The table recorded the years Nigeria gain and loss from engaging in trade relations with Turkey. Also, the year Turkey gain and loss from engaging in trade relations with Nigeria. From the table, it is discovered that Nigerian government gain from gaining in trade relations in 2005, 2007, 2013, 2014 and 2015 while Nigerian Government also loss from engaging in trade in 2000, 2001, 2002, 2003, 2004, 2006, 2008, 2009, 2010, 2011, 2012, 2016, 2017 and 2018. The table also discovered that Turkey government gain from engraining in 2000, 2001, 2002, 2003, 2004, 2006, 2008, 2009, 2010, 2011, 2012, 2016, 2017 and 2018 while loss in 2005, 2007, 2013, 2014 and 2015.

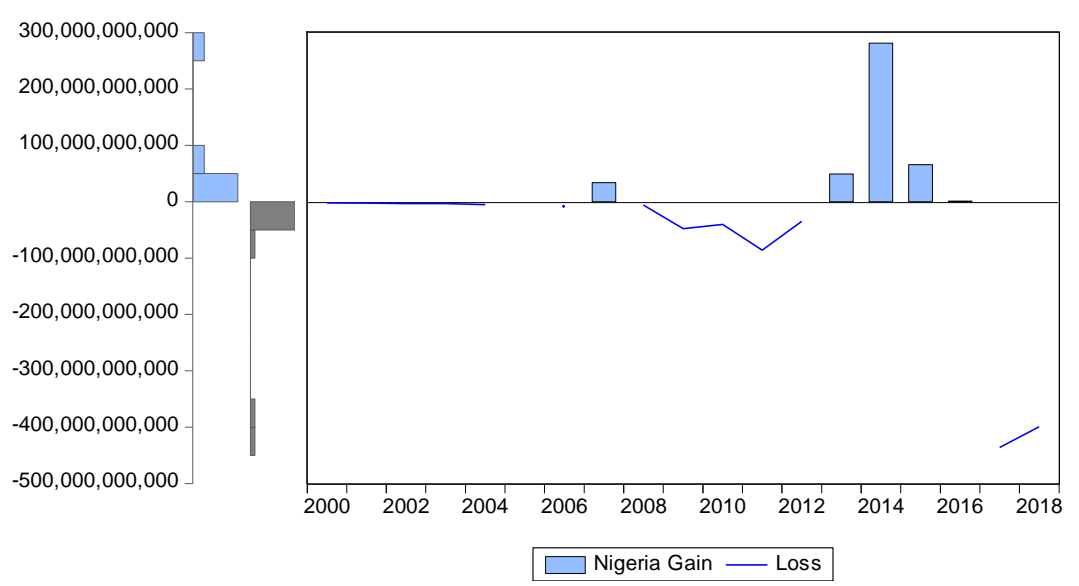

Fig4. Nigeria Trade Loss and Gain from Turkey

The above implies that Nigerian Government gain in trade with Turkey government in 2005, 2007, 2013, 2014 and 2015. The number of years they gain in trade with Turkey government is very small compared to trade loss with Turkey. The years they lost in trade are 2000, 2001, 2002, 2003, 2004, 
2006, 2008, 2009, 2010, 2011, 2012, 2016, 2017 and 2018. The implication of this chart is that Nigeria government eventually lost in with relations with Turkey.

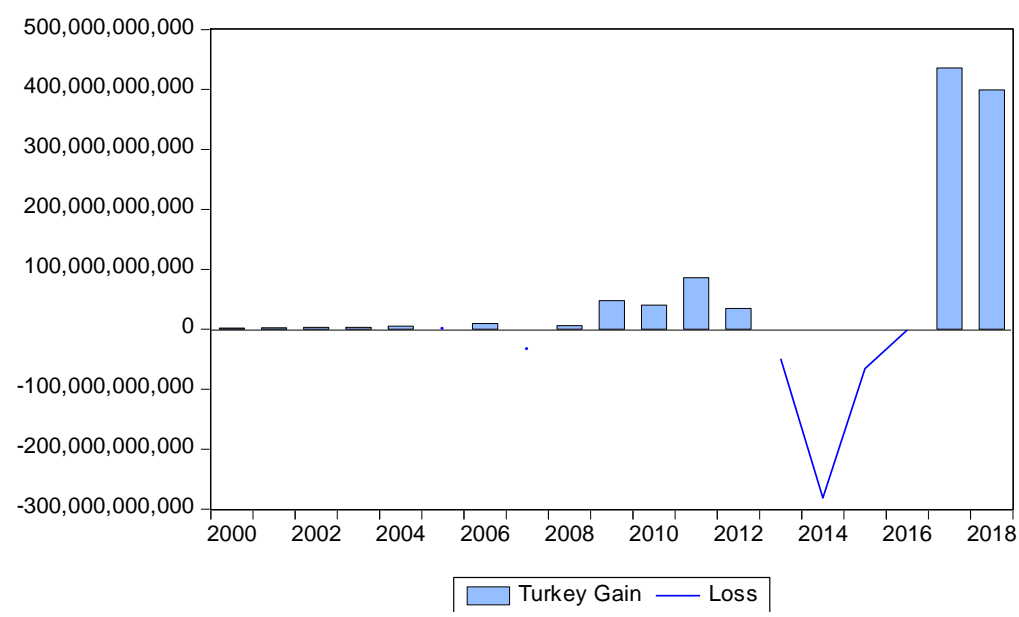

Fig5. Turkey Trade Loss and Gain from Nigeria

The Turkey government lost in trade relations with Nigeria for the period of 2005, 2007, 2013, 2014 and 2015. The period of lost in trade relations with Nigeria is very small compared to the periods of gain in trade that is up to 14 years of gaining from trade in Nigeria. The implication of this is that Turkey gained very well by engaging in trade relations with Nigerian government.

\section{T-Test of Nigeria - Turkey Trade Relations}

One-Sample Statistics

\begin{tabular}{|l|l|l|l|l|}
\hline & N & Mean & Std. Deviation & Std. Error Mean \\
\hline Export & 15 & 76958298558.40 & 95859389334.014 & 24750787897.883 \\
Import & 18 & 69069677267.67 & 131800934486.650 & 31065778180.745 \\
\hline
\end{tabular}

One-Sample Test

\begin{tabular}{|c|c|c|c|c|c|c|}
\hline & \multicolumn{6}{|c|}{ Test Value $=0$} \\
\hline & \multirow[t]{2}{*}{$\mathrm{T}$} & \multirow[t]{2}{*}{ df } & \multirow[t]{2}{*}{ Sig. (2-tailed) } & \multirow[t]{2}{*}{ Mean Difference } & \multicolumn{2}{|c|}{$\begin{array}{l}\text { 95\% Confidence Interval of the } \\
\text { Difference }\end{array}$} \\
\hline & & & & & Lower & Upper \\
\hline Export & 3.109 & 14 & .008 & 76958298558.400 & 23873138159.54 & 130043458957.26 \\
\hline Import & 2.223 & 17 & .040 & 69069677267.667 & 3526614524.42 & 134612740010.91 \\
\hline
\end{tabular}

Source: SPSS, version 20.00

The analysis indicates that export from Nigeria to Turkey and import from Turkey to Nigeria for the period of 2000 to 2018, a 19 years study shown that the variables are significant at a probability value of less than 5\%. The mean value of export is 76958298558.40 and the mean value of import is 69069677267.67. The outcome of the mean value of the two variables showed that export trade is more beneficiary than import trade since the mean value of export is more than the mean value of import. The table also revealed that t-test result showed that export of goods from Nigeria to Turkey is beneficiary to Nigeria while import of goods from Turkey to Nigeria is not beneficiary to Turkey. However, the t-test indicates that Nigeria benefited more from engaging in trade relations with Turkey for the period of 19 years while Turkey do not benefited more from engaging in trade relations with Nigeria for the past 19 years from 2000-2018.

\section{DISCUSSION OF FINDINGS}

The findings of Nigeria - Turkey trade relations for the past 19 years indicate that Nigerian government benefited more from engaging in trade relations with Turkey for the past 19 years while Turkish government benefited less from engaging in trade relations with Nigeria for the past 19 years. The findings showed that the two countries benefited from engaging in trade relations. Nigerian government benefited more from exporting goods from Nigeria to Turkey. The benefited may be because that Nigerian export goods in greater volume or quantity to Turkey than the volume of goods Nigerian government import from Turkey. However, this may also resulted from what Nigerian 
government import from Turkey government. Despite exchange rate imbalances, Nigerian government still gain more from engaging in trade relations with Turkish government.

The Turkey Government also benefited less from engaging in trade relations with Nigerian government for the past 19 years. This may be because the volume of goods import from Turkey is less than what Turkey export from Nigeria. The reason is also that exchange rate of 1 Turkish Iria and 62.95 Nigerian Naira which Turkish government supposed to use in gaining in trade relations with Nigeria is overlooked by the Turkish Government.

\section{CONCLUSION AND RECOMMENDATION}

The study concluded that Nigerian government benefited more from engaging in trade relations with Turkey for the past 19 years while Turkish government benefited less from engaging in trade relations with Nigeria for the past 19 years. The findings showed that the two countries benefited from engaging in trade relations. Nigerian government benefited more from exporting goods from Nigeria to Turkey.

The study recommended that

1. Nigerian Government should increase the volume of export of goods to Turkey since they benefited more from engaging in export of goods from Nigeria to Turkey for the past 19 years. They

should continue to focus on export of agricultural output to

Turkey since Nigerian government benefited more for the past 19 years from 2000-2018

2. Turkish Government should re-strategies on how to gain more from engaging in import trade with Nigerian government. They should use the advantage that their currency is more appreciated than Nigerian currency to gain from trade relations with Nigeria.

\section{REFERENCES}

[1] Republic of Turkeys Ministry of Foreign Affairs (2017). Report on Nigeria - Turkey Trade relations.

[2] Turkish Press Review (2015). Turkish Business in Nigeria.

[3] The Will (2016). The Turkish MOU in Nigeria.

Citation: OPUSUNJU, Michael Isaac et al "Assessment of Turkey-Nigeria Trade Relations from 2000 2018" International Journal of Managerial Studies and Research (IJMSR), vol 8, no. 3, 2020, pp. 27-33. doi: http:// dx.doi.org/10.20431/2349-0349.0803003.

Copyright: $\odot 2020$ Authors. This is an open-access article distributed under the terms of the Creative Commons Attribution License, which permits unrestricted use, distribution, and reproduction in any medium, provided the original author and source are credited. 